Research Article

\title{
Acid and Enzymatic Hydrolyses of Rice Bran for Bioethanol Production
}

\author{
Dewi Yuliani, Khoirul Achmad Julianto, Akyunul Jannah* \\ Chemistry Department, Science and Technology Faculty, Universitas Islam Negeri Maulana Malik Ibrahim, Malang, \\ Indonesia, 65144
}

\section{ARTICLE INFO}

\section{Article History}

Revised 11 October 2018

Accepted 25 November 2018

Available online 30 November 2018

*Email of corresponding author: akyunul_jannah2008@yahoo.com

\section{ABSTRACT}

Rice bran is one among many agricultural by-products containing $50-60 \mathrm{wt} . \%$ of carbohydrate. The carbohydrate is a prominent sugar source for bioethanol production. The objective of this research was to study bioethanol production from rice bran by acid and enzymatic treatment. The variations of acid used were dilute hydrochloric acid and sulphuric acid, while variations of enzyme used were amylolytic and cellulolytic enzyme. Ethanol production of acid-hydrolyzed rice bran was $24.95 \pm 1.61 \%(\mathrm{v} / \mathrm{v})$ by hydrochloric acid and $29.57 \pm 2.04 \%(\mathrm{v} / \mathrm{v})$ by sulphuric acid. Ethanol produced by enzymatic hydrolysis was quite low i.e. $6.7 \pm 0.04 \%$, and $8.86 \pm 0.29 \%(\mathrm{v} / \mathrm{v})$ for amylolytic and cellulolytic hydrolysate, respectively.

Keywords: Bioethanol, rice bran, acid hydrolysis, enzymatic hydrolysis

\section{Introduction}

Energy consumption throughout the world has increased over the past decade including in Indonesia. The high fuel consumptions do not get compensated with the increasing of production. Fifty percent of energy consumption in Indonesia comes from fossil fuel which is a non-renewable energy source. The government is trying to tackle energy issues, particularly by focusing on renewable sources through national energy policy $[1,2,3]$. Bioethanol is an alternative fuel that can be used to reduce our demand on fossil fuel which has depleted the readily available oil sources [4].

As previously reported, bioethanol is widely produced from various lignocellulosic residues such as agricultural byproducts of paddy i.e. rice straw, rice husk, and especially rice bran $[4,5,6]$. Rice bran is the main residue of rice milling and it accounts for $\sim 11 \mathrm{wt} . \%$ of rice. Paddy is one of the most abundant agricultural by-products in Indonesia [7]. As one of rice producing countries in Asia, Indonesia supplies a million tonnes of rice annually and rice bran as by-product. The estimated rice bran generated was around 8.29 million tonnes in 2015 and 8.95 million tonnes in 2017. The amount was predicted to raise in $2018[8,9]$.

The utilization of rice bran is mostly as livestock feed due to its high protein and nutrient content. Rice bran as substrate left over from production processes still contains a high amount of carbon [10]. Rice bran containing two major compounds, it is $\sim 50-60 \%$ carbohydrates and $\sim 20 \%$ lipid that can be applied $[9,11]$. The carbohydrate content in rice bran is a potential source of sugar $[11,12]$. It could be used to boost the value added of rice bran.

Several studies previously shown that rice bran was able to produce bioethanol $[5,10,13,14]$. The application of rice bran as raw material in ethanol production not only will reduce waste material but also lower the bioethanol production cost. The usage of lignocellulosic materials including rice bran requires the treatment process either chemical or enzyme hydrolysis to degrade them into fermentable sugar $[5,15]$. In this study, we compared the effectivity of acidic and enzymatic treatment to hydrolyze rice bran for bioethanol production by Saccharomyces cerevisiae. 


\section{Materials and Methods}

\subsection{Materials}

Commercial rice brain was purchased from Merjosari Market, Dinoyo, Malang. Saccharomyces cerevisicieae, amylolytic bacterium and cellulolytic bacterium were obtained from Biotechnology and Biochemistry Laboratory, Chemistry Department, Universitas Islam Negeri Maulana Malik Ibrahim Malang. The growth media for yeast and bacteria, respectively, were YPGB (Yeast Peptone Glucose Broth) and NB (Nutrient broth). The chemicals used were hydrochloric acid $4 \%$, sulphuric acid $4 \%$, acetate buffer solution $(0.2 \mathrm{M}, \mathrm{pH} 5)$, phosphate buffer solution $(0.2 \mathrm{M}, \mathrm{pH} 7)$, DNS reagent and potassium chromate reagent.

\subsection{Rice Bran Preparation}

One hundred grams of rice bran were washed and sifted with 60 mesh. The determination of initial reducing sugar in sterilized rice bran was carried out with DNS method preceding the hydrolysis process [16].

\subsection{Inoculum Preparation}

Preparation of inoculum was conducted to $S$. cereviceae and the bacteria. The yeast was inoculated on YPGB medium, while both bacteria were inoculated on NB medium. The cultures were kept on incubator shaker at $150 \mathrm{rpm}$, room temperature, $24 \mathrm{~h}$ [17].

\subsection{Acid Hydrolysis of Rice Bran}

Hydrochloric and sulphuric acid were used for rice bran hydrolysis. Twenty grams of rice bran were mixed in $100 \mathrm{~mL}$ distilled water, the mixture was autoclaved at $121^{\circ} \mathrm{C}$ for 15 minutes. The sterilized mixture was added to each of the 100 $\mathrm{mL}$ of $4 \%(\mathrm{v} / \mathrm{v})$ hydrochloric acid and sulfuric acid, separately. The mixture was heated to $100^{\circ} \mathrm{C}$ for 60 minutes in order to hydrolyze the sample. After that, the hydrolysate was cooled down to room temperature and filtered through filter paper to separate water-soluble components $[18,19]$. Acid hydrolysis was performed in triplicate. The filtrate was measured of its reducing sugar by DNS method [16]. A calibration curve using glucose as the standard was established prior to sample measurement.

\subsection{Enzymatic Hydrolysis of Rice Bran}

Amylolytic and cellulolytic bacteria were used as enzyme source. Twenty grams of rice bran were suspended in 100 $\mathrm{mL}$ of acetate buffer and phosphate buffer solution, severally. Afterwards, $15 \mathrm{~mL}$ of amylolytic culture and cellulolytic culture were mixed with the sterilized suspension of acetate and phosphate buffer solution, respectively. The mixture was incubated for $24 \mathrm{~h}, 150 \mathrm{rpm}$, at room temperature to hydrolyze the sample. The hydrolysates were filtered through filter paper [17, 20]. This step was conducted in triplicate. Reducing sugar in filtrate was determined by DNS method [16].

\subsection{Production of Bioethanol}

Four hydrolysates were adjusted to the $\mathrm{pH} 4.5$ and sterilized in autoclave. The sterilized hydrolysates were added with $10 \%(\mathrm{v} / \mathrm{v})$ of $\mathrm{S}$. cerevisiceae culture and incubated for $72 \mathrm{~h}$, at room temperature. Ethanol content in each hydrolysate was analyzed by modified potassium dichromate method [21]. Determination of ethanol content was carried out in triplicate. Sample measurement used ethanol as standard in the calibration curve.

\section{Result and Discussion}

\subsection{Hydrolysis of Rice Bran}

Rice bran contains sugar in the form of polysaccharides such as starch and cellulose. The amount of carbohydrate in RB varies depending on the variety and the original country. Total carbohydrate content in rice bran was $37.72 \%$ from Kaohsiung city, Taiwan [22], 48.3\% from Morelos, Mexico [12] and 48.55-52.33\% from Assam, India [23]. The carbohydrate should be converted to glucose or disaccharide through hydrolysis preceding bioethanol production.

In this study, rice bran was hydrolyzed by acid and enzyme. The acids used were dilute hydrochloric and sulphuric acid, while the enzymes used were amylolytic and cellulolytic enzyme. The reducing sugar (glucose) of the initial rice bran was $0.107 \mathrm{~g} / \mathrm{L}$. Sharma et al. [24] revealed rice bran contains 3-8\% of reducing sugar. Table 1 showed the amount of reducing sugar released after hydrolysis.

The highest conversion of polysaccharide to glucose in RB was performed by sulphuric acid (Table 1). Concentration of glucose produced by sulfuric acid hydrolysis $(0.468 \mathrm{~g} / \mathrm{L})$ was twice higher than that of hydrochloric acid $(0.221 \mathrm{~g} / \mathrm{L})$. It is indicating that sulfuric acid was more efficient than hydrochloric acid to convert polysaccharide in RB. Our result was in 
compliance with Sandi et al. [25] report which stated reducing sugar produced by sulphuric acid is higher than that of hydrochloric acid.

Table 1. Reducing sugar of rice bran after acid and enzymatic hydrolysis

\begin{tabular}{ccc}
\hline No. & Type of Hydrolysis & Glucose formation $\mathbf{( g / L )}$ \\
\hline 1 & Acid Hydrolysis & \\
& Hydrochloric acid & 0.221 \\
& Sulphuric acid & 0.468 \\
2 & Enzymatic Hydrolysis & \\
& Amylase & 0.016 \\
& Cellulase & 0.036 \\
\hline
\end{tabular}

In enzymatic hydrolyses, cellulose and amylase was able to release reducing sugar of 0.036 and $0.016 \mathrm{~g} / \mathrm{L}$. Amylolytic hydrolysis capacity to produce reducing sugar was twice lower than cellulolytic hydrolysis. Tanaka et al. [26] showed different result, in which the addition of amylase was more effective than cellulose. There is a presumption which causes amylase to have low activity to saccharify polysaccharide in RB. The milled RB composed of $27 \%$ of cellulose and $37 \%$ hemicellulose, with low amylose content $(5.66 \%)[14,27]$.

\subsection{Production of Bioethanol}

In this work, bioethanol production was carried out by yeast, S. cerevisiae, to ferment reducing sugar (glucose). The amount of reducing sugar in hydrolysates was then converted to ethanol. The concentration of ethanol produced was 24.95 $\pm 1.61 \%, 29.57 \pm 2.04 \%, 0.67 \pm 0.04 \%$, and $8.86 \pm 0.29 \%(\mathrm{v} / \mathrm{v})$ for hydrochloric acid, sulphuric acid, amylolytic and cellulolytic hydrolysate, respectively (Figure 1).

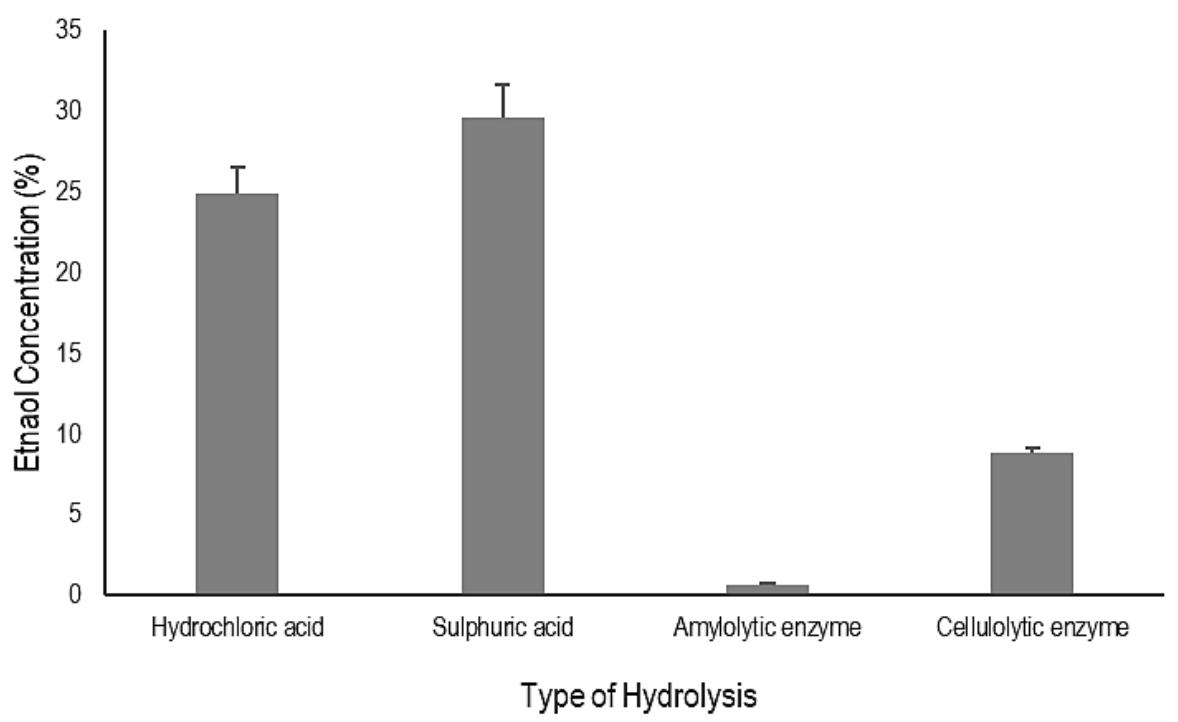

Figure 1. Ethanol production using acid and enzyme mediated hydrolysate of rice bran.

The sugar content (Table 1) was directly proportional to the quantities of the ethanol produced. The higher the sugar content, more ethanol can be produced. The bioethanol production from enzymatic treatment in this study was considerably low if we compared to Harismah et al. [14] with $17.31 \%$ (v/v) of production by the same treatment. However, rice bran subjected to acid treatment prior to fermentation produced higher bioethanol than of Harismah research.

Fermentation of sugarcane bagasse produced ethanol content of $14.8 \%$ (v/v) [28]. Sandi et al. [25] studied the highest bioethanol production from sea weed by Glacilaria sp. was around $8.92 \%$. The bioethanol production from rice bran in this study was higher than the previous report.

\section{Conclusion}

It can be concluded that an agricultural by-product such as rice bran can be used as raw material for ethanol production. The reducing sugar concentration in rice bran varied depending on the type of hydrolysis implemented. 
Bioethanol produced was $24.95 \pm 1.61,29.57 \pm 2.04,0.67 \pm 0.04$, and $8.86 \pm 0.29 \%(v / v)$ for hydrochloric acid, sulphuric acid, amylolytic and cellulolytic hydrolysates, respectively.

\section{References}

[1]. Badan Pengkajian dan Penerapan Teknologi, "Energi Terbarukan, Solusi Krisis Energi Masa Depan," Badan Pengkajian dan Penerapan Teknologi, May 10, 2010. [Online]. Available: https://bppt.go.id/teknologi-informasi-energidan-material/433-energi-terbarukan-solusi-krisis-energi-masa-depan [Accessed: February 18, 2018].

[2]. Dewan Energi Nasional, "Outlook Energi Indonesia 2016, Dewan Energi Indonesia, 2016.

[3]. Agustiyanti, "Indonesia Masih Bergantung Minyak Bumi 30 Tahun ke Depan," October 3, 2017. [Online]. Available: https://www.cnnindonesia.com/ekonomi/20171002202208-85-245665/indonesia-masih-bergantung-minyak-bumi-30tahun-ke-depan [Accessed: February 18, 2018].

[4]. W. Nachaiwieng, S. Lumyong, R. Pratanaphon, K. Yoshioka, \& C. Khanongnuch, "Potential in Bioethanol Production from Various Ethanol Fermenting Microorganism using Rice Husk as Substrate," Biodiversitas, vol. 16, no. 2, pp. 320326, 2015.

[5]. T. Todhanakasem, K. Areerat, P. Thanonkeo, \& R. K. G. M. Young, "The Composition of Rice Bran Hydrolysate and its Possibility to Use in the Ethanol Production by Zymomonas mobilis biofilm," World Academy of Science, Engineering and Technology, International Journal of Biotechnology and Bioengineering, vol. 6, no.12, pp. 1126-1130, 2012.

[6]. N. Yoswathana, P. Phuriphipat, P. Treyawutthiwat, \& M. N. Eshtiaghi, "Bioethanol Production from Rice Straw," Energy Research Journal, vol. 1, no.1, pp. 26-31, 2010.

[7]. T. S. Kahlon, "Rice Bran: Production, Composition, Functionality, and Food Applications, Physiological Benefits," in Fiber Ingredients: Food Applications and Health Benefits 1st Ed., S. S. Cho and P. Samuel. Florida: CRC Press Taylor \& Francis, 2009, pp. 305-318.

[8]. Badan Statistik Inodnesia, "Produksi Padi Menurut Provinsi (ton),1993-2015", Badan Statistik Indonesia, 2015. [Online]. Available: https://www.bps.go.id/linkTableDinamis/view/id/865 [Accessed: February 28, 2018].

[9]. Kementerian Pertanian Republik Indonesia, "Optimis Produksi Beras 2018, Kementan Pastikan Harga Beras Stabil", Kementerian Pertanian Republik Indonesia, 2017. [Online]. Available: http://www.pertanian.go.id/home/?show=news\&act=view\&id=2614. [Accessed: February 28, 2018].

[10]. S. G. Soundari \& V. Sashi, "Ethanol Production by Saccharomyces cerevisiae from Wheat and Rice Bran Hydrolysates of Aspergillus flavus, A. niger and Trichoderma viride," Asian Journal of Bio Science, vol. 5, no.1, pp. 73-36, 2010.

[11]. S. Sutanto, A. W. Go, S. Ismadji, \& Y-H Ju, "Hydrolyzed Rice Bran as Source of Lipid and Solid Acid Catalyst during in situ (Trans)esterification, Biofuels, 2017.

[12]. N. Hernandez, M. E. Rodriguez-Alegria, F. Gonzalez, \& A. Lopez-Mungula, "Enzymatic Treatment of Rice Bran to Improving Processing," Journal of the American Oil Chemists' Society, vol. 77, no. 2, pp. 177-180, 2000.

[13]. S. Tiwari, S. K. Jadhav, \& K. L. Tiwari, "Bioethanol Production from Rice Bran with Optimization of Parameter by Bacillus cereus Strain McR-3," International Journal of Science and Technology, vol.12, pp. 3819-3826, 2015.

[14]. K. Harismah, M. Da'i, A. Asngad, \& Samlawi, "Bioethanol Production from Rice Bran by Saccharomyces cerevisiae," presented at the $1^{\text {st }}$ International and the $4^{\text {th }}$ Congress on Recycling of Organic waste in Agriculture, Isfahan, Iran, 2012.

[15]. J. F. Soares, T. C. Confortin, I. Todero, L. Luft, F. D. Maye, \& M. A. Mazutti, "Diluted Acid Hydrolysis of Rice Waste for Fermentable Sugar Production," presented at XXI Simposio Nacional de Bioprocessos, XII Simposio de Hidrolise Enzimatica de Biomassa, Aracaju, Sergipe, Brasil, 2017.

[16]. G. L. Miller, "Use of Dinitrosalysilic Acid Reagent for Determination of Reducing Sugar," Analytical Chemistry, vol. 3 , pp. 426-428, 1959.

[17]. D. Saropah, A. Jannah, \& A. Maunatin, "Kinetika Reaksi Enzimatis Ekstrak Kasar Enzim Selulase Bakteri Selulolitik Hasil Isolasi dari Bekatul, ALCHEMY, vol. 2, no. 1, pp. 34-45, 2012.

[18]. Z. S. Oslavaldo, P. S. Panca, \& M. Faizal, Pengaruh Konsentrasi Asam dan Waktu pada Proses Hidrolisis dan Fermentasi Pembuatan Bioetanol dari Alang-Alang," Jurnal Teknik Kimia, vol. 18, no. 2, 2012.

[19]. M. J. Taherzadeh \& K. Karimi, "Acid Based Hydrolysis Processes for Ethanol from Lignocellulose Materials: A Review," Bioresources, vol. 2, no. 3, pp. 472-499, 2007.

[20]. E. Novitasari \& N. Herdyastuti, "Screening Bakteri Termofilik Penghasil Enzim Amilase dari Sumber Air Panas Singgahan Tuban, Jawa Timur," UNESA Journal of Chemistry, vol. 3, no.3, pp. 189-193, 2014.

[21]. E. A. Crowel \& C. S. Ough, "A Modified Procedure for Alcohol Determination by Dichromate Oxidation," American Journal of Enology and Viticulture, vol. 30, pp. 61-63, 1979. 
[22]. S. Susanto, A. W. Go, K-H. Chen, P. L. T. Nguyen, S. Ismadji, \& Y-H. Ju, "Release of Sugar by Acid Hydrolysis Form Rice Bran for Single Cell Oil Production and Subsequent in-situ Transesterification for Biodiesel Preparation," Fuel Processing Technology, vol. 167, pp. 281-291, 2017.

[23]. S. Bhosale \& D. Vijayalakshmi, "Processing and Nutritional Composition of Rice Bran," Current Research in Nutrition and Food Science, vol. 3, no. 1, pp. 74-80, 2015.

[24]. H. R. Sharma, G. S. Chauchan, \& K. Agrawal, "Physico-chemical Characteristics of Rice Bran Processed by Dry Heating and Extrusion Cooking, International Journal of Food Properties, vol. 7, pp. 603-614, 2004.

[25]. Y. A. Sandi, W. S. Rita, \& Y. Ciawi, "Hidrolisis Rumput Laut (Glacilaria sp.) Menggunakan Katalis Enzim dan Asam untuk Pembuatan Bioetanol," Jurnal Kimia, vol. 10, no. 1, pp. 7-14, 2016.

[26]. T. Tanaka, M. Hoshina, S. Tanabe, L. Sakai, S. Ohtusubo, \& M. Taniguchi, "Production of D-lactic Acid from Defatted Rice Bran by Simultaneous Saccharification and Fermentation," Bioresource Technology, vol. 97, pp. 211-217, 2006.

[27]. C. Fabian, A. Ayucitra, S. Ismadji, \& Y-H Ju, Isolation and Characterization of Starch from Defatted Rice Bran," Journal of the Taiwan Institute of Chemical Engineers, vol. 42, pp. 86-91, 2011.

[28]. Y. C. Wong \& V. Sanggari, "Bioethanol Production from Sugarcane Bagasse using Fermentation Process," Oriental Journal of Chemistry, vol. 30, no.2, pp. 507-513, 2014. 